OPEN ACCESS

Edited by:

Carlo Caffarelli,

University of Parma, Italy

Reviewed by:

Giuseppe Pingitore,

ASL Roma D, Italy

Yusei Ohshima,

University of Fukui, Japan

*Correspondence:

Konstantinos Douros costasdouros@gmail.com

Specialty section: This article was submitted to Pediatric Pulmonology,

a section of the journal

Frontiers in Pediatrics

Received: 10 April 2017 Accepted: 13 July 2017 Published: 31 July 2017

Citation:

Moustaki M, Loukou I, Tsabouri S and Douros K (2017) The Role of Sensitization to Allergen in Asthma Prediction and Prevention.

Front. Pediatr. 5:166. doi: $10.3389 /$ fped.2017.00166

\section{The Role of Sensitization to Allergen in Asthma Prediction and Prevention}

\author{
Maria Moustaki ${ }^{1}$, loanna Loukou' ${ }^{1}$, Sophia Tsabouri ${ }^{2}$ and Konstantinos Douros ${ }^{3 *}$ \\ ${ }^{1}$ Cystic Fibrosis Unit, "Aghia Sophia" Children's Hospital, Athens, Greece, ${ }^{2}$ Department of Paediatrics, Child Health \\ Department, University of Ioannina School of Medicine, Ioannina, Greece, ${ }^{3}$ Pediatric Allergy and Respiratory Unit, 3rd \\ Department of Pediatrics, "Attikon" Hospital, University of Athens School of Medicine, Athens, Greece
}

The burden of asthma in childhood is considerable worldwide, although some populations are much more affected than others. Many attempts have been made by different investigators to identify the factors that could predict asthma development or persistence in childhood. In this review, the relation between atopic sensitization as an indicator of allergy and asthma in childhood will be discussed. Cross sectional studies, carried out in different countries, failed to show any firm correlation between asthma and atopic sensitization. Birth cohort mainly of infants at high risk for asthma and case-control studies showed that atopic sensitization was a risk factor for current asthma in children older than 6 years. In general, clear relations are observed mostly in affluent Western countries, whereas in less affluent countries, the picture is more heterogeneous. For the prediction of asthma development or persistence in school age children, other prerequisites should also be fulfilled such as family history of asthma and wheezing episodes at preschool age. Despite the conductance of different studies regarding the potential role of allergen avoidance for the primary prevention of childhood asthma, it does not seem that this approach is of benefit for primary prevention purposes. However, the identification of children at risk for asthma is of benefit as these subjects could be provided with the best management practices and with the appropriate secondary prevention measures.

Keywords: allergy, asthma, atopy, prediction, prevalence, prevention, sensitization, wheezing

\section{INTRODUCTION}

Asthma is a very common disease in childhood. In certain countries, such as the USA, it has been estimated that it is the most frequently encountered chronic condition in childhood (1). Asthma affects adults too, but in the majority of cases, the origins of the disease are in the preschool age (2). Childhood asthma is a heterogeneous clinical disorder that includes different phenotypes at different ages (3). This heterogeneity was lucidly illustrated in the Tucson birth cohort study where almost $50 \%$ of children had at least one episode of wheeze until the age of 6 years. In $20 \%$ of these children, wheezing was restricted to the first 3 years of life (transient wheezers), in 15\%, wheezing appeared after the third year of age (late-onset wheezers) and, in almost 15\%, wheezing was present both before 3 years, and it lasted at least until the sixth years of age (persistent wheezers) (4).

From these results, we can surmise that children with wheezing at 6 years of age are unlikely to share the same risk factors with those who never wheezed or who have outgrown wheezing episodes by the age of 6 years. Similar, though not identical, phenotypes of preschool wheezing were also identified by other epidemiological studies $(5,6)$. Their results corroborated that 
only a subset of children with preschool wheezing will have further episodes by the age of 6 years. The above highlights the difficulties in predicting which of the preschool wheezers will eventually develop asthma as the majority will outgrow wheezing episodes by the age of 6 years. Furthermore, Saglani et al. (7) showed that eosinophilic inflammation, which is a characteristic of asthma in older children and adults, was not present in infants with recurrent wheezing and/or cough episodes even in the presence of reversible airflow obstruction. The lack of evidence for any underlying asthmatic-type inflammation and the poor agreement on definitions of different phenotypes of preschool wheezing urged the ERS Task Force in 2008 (8) to suggest not using the term asthma for preschool wheezers. Instead, they proposed the terms episodic (viral) wheeze for children who wheeze intermittently and are well between episodes, and multiple-trigger wheeze for those who wheeze both during and outside discrete episodes. These phenotypes may, however, change over time (9) and, therefore, their validity has been questioned (10).

However, regardless of what classification is used for preschool wheezers, the real challenge is to recognize the risk factors that predispose to the continuation of asthma symptoms in schoolaged children and adolescents. The identification of these risk factors may allow the implementation of effective preventive and therapeutic strategies, to the extent that these factors are modifiable.

Atopy was traditionally considered a risk factor for the development of asthma; allergic march (or atopic march) is a term that has been used for many years to describe the hypothesis of progression from eczema in infancy to rhinitis and asthma in older children (11). According to the most recent definition of World Health Organization, the term "refers to the natural history of atopic manifestations, which is characterized by a typical sequence of immunoglobulin E (IgE) antibody responses and clinical symptoms, which may appear early in life, persist over years or decades, and often remit spontaneously with age" (12). Accordingly, it is considered that a substantial proportion of asthmatic patients have allergic asthma with an underlying IgE-mediated hypersensitivity mechanism and it is, therefore, called IgE-mediated allergic asthma (13). Based on this, it would be plausible to hypothesize that the identification of allergic children could lead to the identification of those at high risk for the development of asthma. Grounded on this hypothesis, many epidemiological studies have investigated whether allergy or atopy was a risk factor for asthma in childhood using either clinical surrogates such as eczema, or biomarkers such as eosinophilia, total IgE, or specific IgE antibodies to certain allergens. Other studies have tried to investigate the relationship between asthma and atopy and to clarify to what extent asthma in children can be attributed to atopy, through the parallel variation of both conditions' prevalence in different populations (14).

The aim of this review is to present the existing data on the relation of atopic sensitization-and its use as an indicator-with asthma in school-aged children, and also the role of allergen exposure for primary prevention of childhood asthma.

\section{PREVALENCE OF ASTHMA AND ATOPY IN CROSS-SECTIONAL STUDIES WORLDWIDE}

The International Study of Asthma and Allergies in Childhood (ISAAC) revealed considerable variability of asthma prevalence among different countries and different regions, and sometimes among different areas of the same country $(15,16)$.

In 1999, Pearce et al. (17) summarized the studies that had evaluated the prevalence of asthma and atopy in children. They reviewed seven such studies from different populations and they concluded that most of them failed to demonstrate an association between asthma and atopy prevalence. Similarly, two other groups summarized the findings of the studies that compared asthma and atopy prevalence in childhood over different time periods and observed that there was either an increase of asthma over time without; however, a parallel increase in atopy $(18,19)$ or, that asthma prevalence was unchanged but the atopy prevalence was increasing.

Ronchetti et al. $(20,21)$ conducted two systematic reviews, and their main findings were the absence of correlation between the prevalence of asthma and the prevalence of atopy, and the existence of a strong correlation between atopy in asthmatic and atopy in the non-asthmatic children; the above imply that the prevalence of atopy in asthma depends on some environmental factors that simultaneously induce atopy in asthmatic and nonasthmatic individuals.

The role of atopic sensitization in the worldwide variation of asthma prevalence was also explored by Weinmayr et al. (22) who conducted cross-sectional studies in 32 centers from 22 countries worldwide in children aged 8-12 years following the ISAAC protocol. They found that current wheeze prevalence rates were not associated with the respective rates of atopic sensitization. However, the fraction of current wheeze attributable to atopic sensitization, as this was determined by skin prick test (SPT) reactivity, was higher in affluent compared to the non-affluent countries (40.7 and 20.3\%, respectively). They also observed that this fraction was strongly correlated with the gross national income.

The above data (22) indicate that the potential link between asthma and atopic sensitization differs between countries and areas; as previous studies have already shown, strong relations are observed mostly in affluent Western countries (23-26), whereas in less affluent countries, the picture is more heterogeneous picture $(24,25,27-29)$.

\section{ATOPY AS A RISK FACTOR FOR CHILDHOOD ASTHMA IN COHORT AND CASE-CONTROL STUDIES}

Many studies have been designed and conducted with the aim to investigate the potential risk factors for the presence of asthma in childhood. Atopic sensitization is among the most commonly investigated risk factors for asthma in childhood. Table $\mathbf{1}$ depicts the characteristics of relevant studies that have been published since 2001. These studies were identified through PubMed 
TABLE 1 | Studies that investigated atopic sensitization as a risk factor for the development of asthma in childhood.

\begin{tabular}{|c|c|c|c|c|c|}
\hline No. & Reference & Study population & $\begin{array}{l}\text { Indicator of atopic } \\
\text { sensitization }\end{array}$ & $\begin{array}{l}\text { Age of } \\
\text { asthma } \\
\text { diagnosis }\end{array}$ & Measured associations \\
\hline 1 & $\begin{array}{l}\text { Alduraywish } \\
\text { et al. (30) }\end{array}$ & $\begin{array}{l}\text { Two independent birth cohorts (1) the } \\
\text { high risk MACS cohort and ( } 2 \text { ) the } \\
\text { population-based LISAplus cohort }\end{array}$ & $\begin{array}{l}\text { (1) MACS cohort: SPTS } \\
\text { to food and inhalant } \\
\text { allergens at } 6,12 \text {, and } \\
24 \text { months } \\
\text { (2) LISApluscohort: slgE } \\
\text { to food and inhalant } \\
\text { allergens at } 2 \text { years }\end{array}$ & $10-12$ years & $\begin{array}{l}\text { The strongest effect on asthma risk was found in } \\
\text { both cohorts, in subjects with co-sensitization } \\
\text { to food allergens and aeroallergens }\end{array}$ \\
\hline 2 & $\begin{array}{l}\text { Boersma } \\
\text { et al. (31) }\end{array}$ & $\begin{array}{l}166 \text { children who visited a hospital with } \\
\text { wheezing at the age } 12-48 \text { months }\end{array}$ & $\begin{array}{l}\text { slgE antibodies to } \\
\text { inhalants allergens } \\
\text { at the age of } \\
12-48 \text { months }\end{array}$ & $\begin{array}{l}\text { At least } \\
6 \text { years }\end{array}$ & $\begin{array}{l}\text { Sensitization to inhalant allergens has a positive } \\
\text { predictive value of } 86 \% \text { for asthma. It remained a } \\
\text { strong predictor for asthma even in multivariate } \\
\text { analysis model }\end{array}$ \\
\hline 3 & $\begin{array}{l}\text { Anderson } \\
\text { et al. (32) }\end{array}$ & $\begin{array}{l}\text { Birth cohort, } 289 \text { newborns at high risk } \\
\text { for asthma }\end{array}$ & $\begin{array}{l}\text { slgE antibodies to } \\
\text { inhalant allergens at } \\
\text { the age of } 2,6 \text {, and } \\
11 \text { years }\end{array}$ & 6 and 11 years & $\begin{array}{l}\text { Sensitization to aeroallergen at } 2 \text { years triples the } \\
\text { risk of asthma at } 6 \text { years and at } 11 \text { years }\end{array}$ \\
\hline 4 & $\begin{array}{l}\text { Gabet } \\
\text { et al. (33) }\end{array}$ & $\begin{array}{l}\text { Birth cohort, 3,860 full term healthy } \\
\text { singletons }\end{array}$ & $\begin{array}{l}\text { slgE antibodies to food } \\
\text { and inhalant allergens } \\
\text { at the age of } 18 \text { months }\end{array}$ & 6 years & $\begin{array}{l}\text { Current symptoms of asthma were significantly } \\
\text { more frequent in children who were mono- or pauci- } \\
\text { sensitized or multi-sensitized }\end{array}$ \\
\hline 5 & $\begin{array}{l}\text { Amin } \\
\text { et al. (34) }\end{array}$ & $\begin{array}{l}\text { Birth cohort, } 762 \text { newborns with a } \\
\text { parent with a positive SPT to at least } \\
1 / 15 \text { aeroallergen, living either }<400 \mathrm{~m} \\
\text { or }>1,500 \mathrm{~m} \text { from a major road }\end{array}$ & $\begin{array}{l}\text { SPTs to aeroallergens, } \\
\text { cow's milk and hen's } \\
\text { egg at the age of } 1,2 \text {, } \\
3,4 \text {, and } 7 \text { years }\end{array}$ & 7 years & $\begin{array}{l}\text { Sensitization to }>1 \text { aeroallergen at } 12 \text { months of age } \\
\text { or at } 3 \text { years was more frequent among children with } \\
\text { asthma at } 7 \text { years. The same was true for sensitization } \\
\text { to egg, but not for sensitization to cow's milk }\end{array}$ \\
\hline 6 & $\begin{array}{l}\text { Rø } \\
\text { et al. (35) }\end{array}$ & $\begin{array}{l}\text { Subpopulation of a birth cohort, } 668 \\
\text { children evaluated at } 2 \text { years of age } \\
\text { from the PACT study birth cohort }\end{array}$ & $\begin{array}{l}\text { slgE antibodies and } \\
\text { SPT to nine allergens at } \\
2 \text { years of age }\end{array}$ & 6 years & $\begin{array}{l}\text { Positive slgE was associated with a significantly } \\
\text { increased risk for asthma at the age of } 6 \text { years in the } \\
\text { unadjusted for confounders model }\end{array}$ \\
\hline 7 & $\begin{array}{l}\text { van der Mark } \\
\text { et al. (36) }\end{array}$ & $\begin{array}{l}\text { A cohort of } 771 \text { children, aged } \\
1-5 \text { years, who visited primary care } \\
\text { clinics during the preceding } 12 \text { months } \\
\text { with complaints of recurrent coughing, } \\
\text { wheezing, and/or shortness of breath }\end{array}$ & $\begin{array}{l}\text { slgE antibodies to dog, } \\
\text { cat, HDM }\end{array}$ & 6 years & $\begin{array}{l}\text { Positive slgE doubled the risk for asthma diagnosis } \\
\text { at the age of } 6 \text { years }\end{array}$ \\
\hline 8 & $\begin{array}{l}\text { Stoltz } \\
\text { et al. (37) }\end{array}$ & $\begin{array}{l}\text { Birth cohort, } 289 \text { newborns at high } \\
\text { risk for asthma and allergic disease } \\
\text { development }\end{array}$ & $\begin{array}{l}\text { slgE antibodies to } \\
\text { aeroallergens at the age } \\
\text { of } 1,3,6 \text {, and } 9 \text { years }\end{array}$ & 6 and 8 years & $\begin{array}{l}\text { At the age of } 1 \text { year, only sensitization to dog and } \\
\text { to cat was significantly associated with asthma } \\
\text { risk. At the age of } 3 \text { years, sensitization to any } \\
\text { perennial allergen was associated with asthma risk }\end{array}$ \\
\hline 9 & $\begin{array}{l}\text { Llanora } \\
\text { et al. (38) }\end{array}$ & $\begin{array}{l}\text { Cohort study, } 78 \text { preschool children } \\
\text { 2-5 years with at least one wheezing } \\
\text { episode }\end{array}$ & SPTs to HDM & 8-14 years & $\begin{array}{l}\text { Children with positive SPT had a twofold higher risk } \\
\text { for persistent wheezing at the age 8-14 years }\end{array}$ \\
\hline 10 & $\begin{array}{l}\text { Amat } \\
\text { et al. (39) }\end{array}$ & $\begin{array}{l}541 \text { infants under } 36 \text { months of age } \\
\text { who had a history of at least three } \\
\text { wheezing episodes }\end{array}$ & $\begin{array}{l}\text { slgE antibodies to food } \\
\text { and inhalant allergens }\end{array}$ & 13 years & $\begin{array}{l}\text { Allergen polysensitization (irrespective of the type of } \\
\text { allergen), sensitization to multiple aeroallergens } \\
\text { and to multiple food allergens were all associated } \\
\text { with persistent active asthma }\end{array}$ \\
\hline 11 & $\begin{array}{l}\text { Lodge } \\
\text { et al. (40) }\end{array}$ & $\begin{array}{l}\text { Birth cohort, } 620 \text { infants with a family } \\
\text { history of asthma/eczema/allergic } \\
\text { rhinitis/severe food allergy }\end{array}$ & $\begin{array}{l}\text { SPTs to food allergens } \\
\text { and aeroallergens at } \\
\text { the age of } 6,12 \text {, and } \\
24 \text { months }\end{array}$ & 12 years & $\begin{array}{l}\text { Sensitization to HDM at the age of } 12 \text { and } 24 \text { months } \\
\text { increased the odds for asthma at } 12 \text { years }\end{array}$ \\
\hline 12 & $\begin{array}{l}\text { Vial Dupuy } \\
\text { et al. (41) }\end{array}$ & $\begin{array}{l}200 \text { children who visited a pediatric } \\
\text { pulmonology clinic with recurrent } \\
\text { wheezing as infants ( }<2 \text { years) }\end{array}$ & $\begin{array}{l}\text { slgE antibodies to food } \\
\text { allergens and inhalant } \\
\text { allergens }\end{array}$ & 6 years & $\begin{array}{l}\text { Polysensitization increased the odds for persistent } \\
\text { asthma at } 6 \text { years of age }\end{array}$ \\
\hline 13 & $\begin{array}{l}\text { Caudri } \\
\text { et al. (42) }\end{array}$ & $\begin{array}{l}\text { Subpopulation of the PIAMA birth } \\
\text { cohort, } 848 \text { children who were invited } \\
\text { at the age of } 3-4 \text { years. For evaluation, } \\
\text { they had at least one respiratory } \\
\text { symptom suggestive of asthma }\end{array}$ & $\begin{array}{l}\text { slgE antibodies to } \\
\text { inhalant allergens }\end{array}$ & $5-8$ years & $\begin{array}{l}\text { A positive slgE to any airborne allergen increased } \\
\text { the odds for wheezing at the age of } 8 \text { years }\end{array}$ \\
\hline
\end{tabular}


TABLE 1 | Continued

\begin{tabular}{|c|c|c|c|c|c|}
\hline No. & Reference & Study population & $\begin{array}{l}\text { Indicator of atopic } \\
\text { sensitization }\end{array}$ & $\begin{array}{l}\text { Age of } \\
\text { asthma } \\
\text { diagnosis }\end{array}$ & Measured associations \\
\hline 14 & $\begin{array}{l}\text { Lødrup Carlsen } \\
\text { et al. (43) }\end{array}$ & $\begin{array}{l}\text { Nested case-control study, } 265 \\
\text { children, } 2 \text { years old with recurrent } \\
\text { (>2 episodes) or persistent (>4 weeks } \\
\text { duration) doctor confirmed bronchial } \\
\text { obstruction, and } 251 \text { controls without } \\
\text { bronchial obstruction }\end{array}$ & $\begin{array}{l}\text { slgE antibodies to food } \\
\text { and inhalant allergens }\end{array}$ & 10 years & $\begin{array}{l}\text { The probability of current asthma at } 10 \text { years of age } \\
\text { increased with increasing levels of slgE antibodies to } \\
\text { a mix of allergens measured at } 2 \text { years of age. This } \\
\text { finding was significant only for boys }\end{array}$ \\
\hline 15 & $\begin{array}{l}\text { Simpson } \\
\text { et al. (44) }\end{array}$ & $\begin{array}{l}\text { A population-based birth cohort } \\
\text { (Manchester Asthma and Allergy } \\
\text { Study), 1,186 participants who were } \\
\text { recruited at birth and followed at ages } \\
1,3,5 \text {, and } 8 \text { years }\end{array}$ & $\begin{array}{l}\text { slgE antibodies and } \\
\text { SPTs to food and } \\
\text { inhalant allergens }\end{array}$ & 8 years & $\begin{array}{l}\text { Multiple early atopic sensitization was strongly } \\
\text { associated with current wheeze at the age of } 8 \text { years. } \\
\text { This type of sensitization predicts not only the } \\
\text { presence but also the persistence of asthma }\end{array}$ \\
\hline 16 & $\begin{array}{l}\text { Marenholz } \\
\text { et al. (45) }\end{array}$ & $\begin{array}{l}\text { 1,314 children of German MAS birth } \\
\text { cohort }\end{array}$ & $\begin{array}{l}\text { slgE antibodies to food } \\
\text { allergens }\end{array}$ & $\begin{array}{l}7, \text { and/or } \\
10, \text { and/or } \\
13 \text { years }\end{array}$ & Food sensitization increased the odds for asthma \\
\hline 17 & $\begin{array}{l}\text { Jackson } \\
\text { et al. (46) }\end{array}$ & $\begin{array}{l}\text { Birth cohort, } 289 \text { newborns with at } \\
\text { least one parent with one or more } \\
\text { positive aeroallergen SPT and/or a } \\
\text { history of physician diagnosed asthma }\end{array}$ & $\begin{array}{l}\text { slgE to aeroallergens } \\
\text { and food allergens } \\
\text { at } 1 \text { and } 3 \text { years of } \\
\text { age, plus SPTs to } 12 \\
\text { aeroallergens at } 5 \text { years } \\
\text { of age }\end{array}$ & 6 years of age & $\begin{array}{l}\text { Aeroallergen sensitization at the age of } 1 \text { and } 3 \text { years } \\
\text { was associated with increased risk for asthma at the } \\
\text { age of } 6 \text { years }\end{array}$ \\
\hline 18 & $\begin{array}{l}\text { Devulapalli } \\
\text { et al. (47) }\end{array}$ & $\begin{array}{l}\text { Nested case-control study } \\
\text { Children aged } 2 \text { years, } 265 \text { cases } \\
\text { with recurrent or persistent doctor } \\
\text { confirmed bronchial obstruction and } \\
251 \text { controls (the same population as } \\
\text { in study No. 14) }\end{array}$ & $\begin{array}{l}\text { SPTs to food allergens } \\
\text { and aeroallergens at } \\
\text { the age of } 2 \text { years }\end{array}$ & 10 years & $\begin{array}{l}\text { Atopic sensitization at the age of } 2 \text { years did not differ } \\
\text { between asthmatic and non-asthmatic children at the } \\
\text { age of } 10 \text { years }\end{array}$ \\
\hline 19 & $\begin{array}{l}\text { Just } \\
\text { et al. (48) }\end{array}$ & $\begin{array}{l}\text { A cohort of } 219 \text { infants }<30 \text { months } \\
\text { with recurrent wheezing episodes }\end{array}$ & $\begin{array}{l}\text { slgE antibodies to } \\
\text { aeroallergens and food } \\
\text { allergens }\end{array}$ & 6 years & $\begin{array}{l}\text { In univariate analysis, allergic sensitization to at least } \\
\text { one component of tested allergens was associated } \\
\text { with persistence of wheezing at the age of } 6 \text { years. } \\
\text { Absence of eosinophilia in combination with absence } \\
\text { of allergic sensitization discriminated correctly } 96 \% \text { of } \\
\text { children with wheezing in remission }\end{array}$ \\
\hline 20 & $\begin{array}{l}\text { Piippo-Savolainen } \\
\text { et al. (49) }\end{array}$ & $\begin{array}{l}\text { A cohort of } 83 \text { children }<2 \text { years who } \\
\text { were hospitalized for bronchiolitis }\end{array}$ & $\begin{array}{l}\text { slgE antibodies to } \\
\text { aeroallergens }\end{array}$ & $\begin{array}{l}8.5-10 \text { and } \\
13.5-15 \text { years }\end{array}$ & $\begin{array}{l}\text { Early sensitization to seasonal pollens was associated } \\
\text { with asthma at the age of } 13.5-16 \text { years }\end{array}$ \\
\hline 21 & $\begin{array}{l}\text { Eysink } \\
\text { et al. (50) }\end{array}$ & $\begin{array}{l}\text { Cohort study, } 752 \text { children } 1-4 \text { years } \\
\text { who had visited GP complaining for } \\
\text { cough for at least the preceding } 5 \text { days }\end{array}$ & $\begin{array}{l}\text { slgE antibodies to cat, } \\
\text { dog, and HDM }\end{array}$ & 6 years & $\begin{array}{l}\text { Sensitization by the age of } 4 \text { years was a prognostic } \\
\text { indicator of asthma }\end{array}$ \\
\hline 22 & $\begin{array}{l}\text { Arshad } \\
\text { et al. (51) }\end{array}$ & $\begin{array}{l}\text { Whole population birth cohort in the } \\
\text { Isle of Wight, 1,456 newborns }\end{array}$ & $\begin{array}{l}\text { SPTs to aeroallergens } \\
\text { and food allergens }\end{array}$ & 10 years & $\begin{array}{l}\text { Asthma was associated with positive SPT at the age } \\
\text { of } 4 \text { years }\end{array}$ \\
\hline 23 & $\begin{array}{l}\text { Kotaniemi-Syrjänen } \\
\text { et al. (52) }\end{array}$ & $\begin{array}{l}\text { A cohort of } 100 \text { infants aged } \\
1-23 \text { months who were hospitalized } \\
\text { with infection-related wheezing }\end{array}$ & $\begin{array}{l}\text { slgE antibodies to } \\
\text { aeroallergens and food } \\
\text { allergens }\end{array}$ & $5.6-8.8$ years & $\begin{array}{l}\text { Positive slgE (>0.35 kU/L) to aeroallergens was } \\
\text { associated with the risk of school age asthma. The } \\
\text { same was true for slgE positive test to a mixture of } \\
\text { food allergens but with a cut off value of } 0.70 \mathrm{kU} / \mathrm{L}\end{array}$ \\
\hline 24 & $\begin{array}{l}\text { Illi } \\
\text { et al. (53) }\end{array}$ & $\begin{array}{l}\text { 1,314 children of German MAS birth } \\
\text { cohort }\end{array}$ & $\begin{array}{l}\text { slgE antibodies to } \\
\text { food allergens and } \\
\text { aeroallergens at } 1,2,3 \text {, } \\
5,6 \text {, and } 7 \text { years of age }\end{array}$ & 7 years & $\begin{array}{l}\text { Transient sensitization was not a risk factor for } \\
\text { asthma at the age of } 7 \text { years. Children with persistent } \\
\text { sensitization had increased risk for asthma at the age } \\
\text { of } 7 \text { years provided that there was a positive parental } \\
\text { history of asthma or atopy }\end{array}$ \\
\hline
\end{tabular}

SPT, skin prick test; HDM, house dust mite; BHR, bronchial hyperresponsiveness; slgE, serum immunoglobulin E (IgE); OR, odds ratio; Cl: 95\% confidence interval.

searching, using the following terms: allergy, atopy, SPT, IgE, RAST, sensitization, children, asthma, and prediction.

Studies referring to population of preschool children were excluded since asthma is not well defined in this age. Definition of current asthma at the age of 6-14 years was not identical among different studies. However, all studies had as a prerequisite evidence of asthma symptoms during the preceding 12 months. It should be also noted that the majority of studies included 
population at high risk for asthma either because of the parental history or because the population was recruited with respiratory symptoms suggestive of bronchiolitis or wheezing episodes. Despite their heterogeneity, the majority of the presented studies pointed to the same direction, namely, that atopic sensitization of infants or toddlers was associated with increased risk for asthma later in childhood.

Asthma predictive models have also been used in order to assess the probability of a toddler to have asthma as a child. Some of these models included sensitization to allergens in their scoring system. In 2003, Kurukulaaratchy et al. (54) developed a scoring system derived from a birth cohort of Isle of Wight. Although this cohort included all the neonates that were born in 1989 irrespective of their risk level for asthma, the predictive model was a combination of recurrent chest infections at 2 years, atopic sensitization at 4 years, a family history of asthma, and absence of nasal symptoms at 12 months of age. Another predictive model that included atopic sensitization either to at least one aeroallegen or to specific food allergens was the modified asthma predictive index (API) (55), which was derived from the API (56) that was developed in 2000 by Castro-Rodriguez et al. It is, therefore, obvious that atopic sensitization per se has not adequate accuracy for the prediction of asthma occurrence in childhood, but it can be used in combination with other risk factors for the prediction of persistence of asthma among preschool wheezers.

It is also of interest to mention that there are studies that investigated if there was a pattern of sensitization that was associated with asthma in childhood. Illi et al. (53) found that transient early sensitization was not associated with an excess risk for asthma in childhood (7 years of age). In cases of persistent atopic sensitization, the risk for childhood asthma increased only in those children with a concomitant maternal history of asthma. However, when sensitization to food allergens was examined separately from that to inhalant allergen, it was shown that early sensitization to food allergens increased the risk for asthma development up to school age. On the contrary, early sensitization to inhalant allergens without concomitant sensitization to food allergens did not confer any excess risk for asthma development up to school age. More recently, Alduraywish et al. (30) showed that early sensitization either to food allergens or to aeroallergens was associated with increased risk for asthma in childhood. However, the strongest effect on asthma risk was observed in children with concurrent sensitization to food and inhalant allergens. In the latter study (30), there are no data regarding persistence of sensitization as available information is restricted to the age of 24 months. On the other hand, Simpson et al. (57) using a similar approach found that multiple early sensitization has the strongest association with asthma at the age of 8 years. However, they concluded that $\operatorname{IgE}$ antibody responses do not represent a single phenotype of atopy, but rather, several different atopic vulnerabilities, which vary in their relation with asthma presence and severity. In their study, there were no data regarding parental history of asthma or atopy and, so, it is not possible to make direct comparisons with Illi et al.'s findings.

A different pattern of atopic sensitization in relation to childhood asthma risk was identified by Stoltz et al. (37). In their birth cohort study, only sensitization to dog and cat at the first year of life or sensitization to any of the perennial allergens tested was associated with asthma risk at the age of 6 years.

Although it is well recognized that atopy does not equate to atopic sensitization (58), it seems that the latter serves as a good surrogate of atopy. Most likely, the latter constitutes a risk factor for asthma in childhood only when other prerequisites coexist such as history of infant wheezing, parental history of asthma, or parental history of atopy. Therefore, it cannot be considered a satisfactory indicator for predicting or ruling out asthma in childhood without first taking into account these factors. This comes as no surprise since asthma is a multifactorial entity dependent on genetic predispositions and environmental exposures. Based on the available evidence, wheezy toddlers with a positive family history of asthma and presence of atopic sensitization should be regarded as high risk for persistence of asthma in childhood. Similarly, in a recent systematic review, Rotriguez-Martinez et al. (59) included allergic sensitization early in life (especially polysensitization) among the factors that confer to the prediction of wheezing persistence through school age.

\section{THE ROLE OF ALLERGY IN THE PREVENTION OF ASTHMA}

Predicting the risk of childhood asthma development or persistence would be of great importance as it could facilitate the design of primary prevention measures. The last decade of the previous century, it was hypothesized that primary prevention strategies in terms of allergen avoidance for infants at high risk for asthma would be of benefit. Nowadays, it has been recognized that prevention of asthma is not so straightforward as it seemed due to the multifactorial nature of the disease.

Many different interventional studies have been conducted over the last 20 years that tested the efficacy of allergen avoidance in the prevention of asthma. A recent meta-analysis (60) examined the mono- and multifaceted intervention studies until 2011. They found that monofaceted intervention studies versus control did not lead to any reduction in childhood asthma occurrence. In contrast, multifaceted intervention studies were associated with a reduction by half of asthma diagnosis in childhood. Three intervention studies were characterized as multifaceted and were included in this meta-analysis and in two of them the asthma outcome was reported at an age older than 6 years $(51,61)$. Both studies included interventions regarding reduction of house dust mite and food exposure, whereas the Canadian study (61) also included measures for pet avoidance and reduction in environmental tobacco smoke. Both studies included children at high risk for developing asthma and, therefore, their results are not applicable in the general population. Furthermore, taking into consideration that asthma risk attributed to atopy varied substantially between affluent and non-affluent countries, the same intervention measures may not be of value in other population settings even in children at high risk for asthma.

The outcome is noteworthy not only for the ineffectivenes of the monofaceted interventions but also because it generated a new hypothesis that had to be tested: that early exposure to specific allergens may lead to tolerance instead of allergy. It was 
shown (62) that chronic exposure to high concentrations of cat allergens can promote a modified immune response consisting of a reduction in specific IgE immunoglobulins and an increase in specific IgG immunoglobulins, especially IgG4. Similarly, Stoltz et al. (37) found that although sensitization to dog was associated with increased asthma risk, dog exposure at birth was associated with a reduced asthma risk irrespective of sensitization status to $\mathrm{dog}$, at any point during the first 6 years of life. The aspect of tolerance development through early exposure has also been evident in the area of food allergy. Tolerance to peanuts was developed in infants through the early introduction of peanut in their diet instead of strict avoidance whereas high maternal consumption of peanuts during pregnancy reduced the risk of peanut allergy in the offspring (63). These observations goes in parallel with the results of a recent meta-analysis (64), which showed that maternal dietary restriction during pregnancy or lactation failed to reduce the child's risk for atopic disease. There is no evidence that any modification of the weaning procedure could help in the prevention of atopic diseases, and so, such interventions are not recommended (65).

Having taken into account all recent evidence, the German updated guidelines on allergy prevention, published in 2014 (66), do not recommend any restriction in maternal diet during pregnancy and during lactation. They also do not recommend any measures for the reduction of house dust mite exposure for primary prevention purposes. However, they recommended avoidance of exposure to tobacco smoke and other indoor air pollutants as well as indoor conditions that promote mold. They also recommended some other measures of prevention that seem to affect the risk of asthma such as avoidance of obesity and avoidance of cesarean section.

More recently, in an international report about the implications of indoor allergen avoidance in asthma prevention and management, it was also acknowledged that the results for HDM avoidance and asthma prevention were inconsistent. The authors attributed this discrepancy to the type of approach (multifaceted or monofaceted), to the initial level of indoor HDM allergen, and possibly to genetic or other environmental co-factors (67).

Therefore, based on the existing evidence, allergen avoidance cannot confer sufficiently to the primary prevention of asthma

\section{REFERENCES}

1. O'Connell EJ. The burden of atopy and asthma in children. Allergy (2004) 59(s78):7-11. doi:10.1111/j.1398-9995.2004.00563.x

2. Bisgaard H, Bønnelykke K. Long-term studies of the natural history of asthma in childhood. J Allergy Clin Immunol (2010) 126(2):187-97. doi:10.1016/j. jaci.2010.07.011

3. Reddel HK, Bateman ED, Becker A, Boulet L-P, Cruz AA, Drazen JM, et al. A summary of the new GINA strategy: a roadmap to asthma control. Eur Respir J (2015) 46(3):622-39. doi:10.1183/13993003.00853-2015

4. Martinez FD, Wright AL, Taussig LM, Holberg CJ, Halonen M, Morgan WJ. Asthma and wheezing in the first six years of life. N Engl J Med (1995) 332(3):133-8. doi:10.1056/nejm199501193320301

5. Rusconi F, Galassi C, Corbo GM, Forastiere F, Biggeri A, Ciccone G, et al. Risk factors for early, persistent, and late-onset wheezing in young children. Am J Respir Crit Care Med (1999) 160(5):1617-22. doi:10.1164/ajrccm.160.5.9811002

6. Henderson J, Granell R, Heron J, Sherriff A, Simpson A, Woodcock A, et al. Associations of wheezing phenotypes in the first 6 years of life with atopy, in childhood. Allergen exposure may increase the risk of atopic consequences, but the outcome is highly dependent on the dose and kind of allergen, timing of exposure, and vulnerability of the child (68). Nevertheless, it is of benefit to identify those infants who are at increased risk for the development of asthma in order to (a) intensify the implementation of measures of primary prevention according to the existing guidelines (66) and (b) provide them the best practice management, close clinical monitoring, and measures of secondary prevention.

\section{CONCLUSION}

Atopic sensitization is related with an increased risk for asthma in childhood, but the extent of this association varies considerably among different populations and there is a pronounced difference between affluent and non-affluent countries; strong relations are observed mostly in affluent Western countries, whereas in less affluent countries, a more heterogeneous picture is observed.

Atopic sensitization per se does not predict development or persistence of asthma in childhood although it seems that atopic sensitization is associated with development of asthma in patients with wheezing.

Although allergen avoidance had been considered as a potential preventive measure from asthma development in high risk children, the majority of intervention studies failed to show positive results.

The identification, however, of infants at high risk for the development or persistence of asthma in childhood, it remains of benefit as these subjects should be provided with the best practice management.

\section{AUTHOR CONTRIBUTIONS}

MM, co-designed the structure of the paper, wrote most of the manuscript, reviewed, and approved the final manuscript. KD: co-designed the structure of the paper, wrote some parts of the manuscript, reviewed, corrected, and approved the final manuscript. IL and ST: searched PubMed and libraries and found the available literature and wrote some parts of the manuscript.

lung function and airway responsiveness in mid-childhood. Thorax (2008) 63(11):974-80. doi:10.1136/thx.2007.093187

7. Saglani S, Malmström K, Pelkonen AS, Malmberg LP, Lindahl H, Kajosaari M, et al. Airway remodeling and inflammation in symptomatic infants with reversible airflow obstruction. Am J Respir Crit Care Med (2005) 171(7):722-7. doi:10.1164/rccm.200410-1404oc

8. Brand PLP, Baraldi E, Bisgaard H, Boner AL, Castro-Rodriguez JA, Custovic A, et al. Definition, assessment and treatment of wheezing disorders in preschool children: an evidence-based approach. Eur Respir J (2008) 32(4):1096-110. doi:10.1183/09031936.00002108

9. Schultz A, Devadason SG, Savenije OEM, Sly PD, Le Souëf PN, Brand PLP. The transient value of classifying preschool wheeze into episodic viral wheeze and multiple trigger wheeze. Acta Paediatr (2009) 99(1):56-60. doi:10.1111/j.1651-2227.2009.01508.x

10. Cowan K, Guilbert TW. Pediatric asthma phenotypes. Curr Opin Pediatr (2012) 24(3):344-51. doi:10.1097/mop.0b013e32835357ab

11. Ker J, Hartert TV. The atopic march: what's the evidence? Ann Allergy Asthma Immunol (2009) 103(4):282-9. doi:10.1016/s1081-1206(10)60526-1 
12. World Allergy Organization. The Allergic March. (2005). Available from: http:// www.worldallergy.org/professional/allergic_diseases_center/allergic_march/

13. Johansson SGO, Bieber T, Dahl R, Friedmann PS, Lanier BQ, Lockey RF, et al. Revised nomenclature for allergy for global use: report of the nomenclature review committee of the world allergy organization, October 2003. J Allergy Clin Immunol (2004) 113(5):832-6. doi:10.1016/j.jaci.2003.12.591

14. Douros K, Loukou I, Boutopoulou B, Fouzas S. Does vitamin D deficiency epidemic parallel with allergy and asthma epidemic? Mini Rev Med Chem (2015) 15(12):967-73. doi:10.2174/138955751512150731110827

15. Mallol J, Crane J, von Mutius E, Odhiambo J, Keil U, Stewart A. The international study of asthma and allergies in childhood (ISAAC) phase three: a global synthesis. Allergol Immunopathol (Madr) (2013) 41(2):73-85. doi:10.1016/j. aller.2012.03.001

16. Beasley R. Worldwide variation in prevalence of symptoms of asthma, allergic rhinoconjunctivitis, and atopic eczema: ISAAC. Lancet (1998) 351(9111):1225-32. doi:10.1016/s0140-6736(97)07302-9

17. Pearce N, Pekkanen J, Beasley R. How much asthma is really attributable to atopy? Thorax (1999) 54(3):268-72. doi:10.1136/thx.54.3.268

18. Peat JK, Van Den Berg RH, Green WF, Mellis CM, Leeder SR, Wolcock AJ. Changing prevalence of asthma in Australian children. BMJ (1994) 308(6944):1591-6. doi:10.1136/bmj.308.6944.1591

19. von Mutius E, Weiland SK, Fritzsch C, Duhme H, Keil U. Increasing prevalence of hay fever and atopy among children in Leipzig, East Germany. Lancet (1998) 351(9106):862-6. doi:10.1016/s0140-6736(97)10100-3

20. Ronchetti R, Rennerova Z, Barreto M, Villa MP. The prevalence of atopy in asthmatic children correlates strictly with the prevalence of atopy among nonasthmatic children. Int Arch Allergy Immunol (2006) 142(1):79-85. doi:10.1159/000096031

21. Ronchetti R, Jesenak M, Rennerova Z, Barreto M, Ronchetti F, Villa MP. Relationship between atopic asthma and the population prevalence rates for asthma or atopy in children: atopic and nonatopic asthma in epidemiology. Allergy Asthma Proc (2009) 30(1):55-63. doi:10.2500/aap.2009.30.3197

22. Weinmayr G, Weiland SK, Björkstén B, Brunekreef B, Büchele G, Cookson WOC, et al. Atopic sensitization and the international variation of asthma symptom prevalence in children. Am J Respir Crit Care Med (2007) 176(6):565-74. doi:10.1164/rccm.200607-994oc

23. Sunyer J, Jarvis D, Pekkanen J, Chinn S, Janson C, Leynaert B, et al. Geographic variations in the effect of atopy on asthma in the European Community Respiratory Health study. J Allergy Clin Immunol (2004) 114(5):1033-9. doi:10.1016/j.jaci.2004.05.072

24. Braback L, Breborowicz A, Dreborg S, Knutsson A, Pieklik H, Bjorksten B. Atopic sensitization and respiratory symptoms among Polish and Swedish school children. Clin Exp Allergy (1994) 24(9):826-35. doi:10.1111/ j.1365-2222.1994.tb01805.x

25. von Mutius E, Martinez FD, Fritzsch C, Nicolai T, Roell G, Thiemann HH. Prevalence of asthma and atopy in two areas of West and East Germany. Am J Respir Crit Care Med (1994) 149(2 Pt 1):358-64. doi:10.1164/ ajrccm.149.2.8306030

26. Arshad SH, Tariq SM, Matthews S, Hakim E. Sensitization to common allergens and its association with allergic disorders at age 4 years: a whole population birth cohort study. Pediatrics (2001) 108(2):E33. doi:10.1542/ peds.108.2.e33

27. Yemaneberhan H, Bekele Z, Venn A, Lewis S, Parry E, Britton J. Prevalence of wheeze and asthma and relation to atopy in urban and rural Ethiopia. Lancet (1997) 350(9071):85-90. doi:10.1016/s0140-6736(97)01151-3

28. Sunyer J, Torregrosa J, Anto JM, Menendez C, Acosta C, Schellenberg D, et al. The association between atopy and asthma in a semirural area of Tanzania (East Africa). Allergy (2000) 55(8):762-6. doi:10.1034/j.1398-9995.2000.00657.x

29. Penny ME, Murad S, Madrid SS, Herrera TS, Pineiro A, Caceres DE, et al. Respiratory symptoms, asthma, exercise test spirometry, and atopy in schoolchildren from a Lima shanty town. Thorax (2001) 56(8):607-12. doi:10.1136/ thorax.56.8.607

30. Alduraywish SA, Standl M, Lodge CJ, Abramson MJ, Allen KJ, Erbas B, et al. Is there a march from early food sensitization to later childhood allergic airway disease? Results from two prospective birth cohort studies. Pediatr Allergy Immunol (2017) 28(1):30-7. doi:10.1111/pai.12651

31. Boersma NA, Meijneke RWH, Kelder JC, van der Ent CK, Balemans WAF. Sensitization predicts asthma development among wheezing toddlers in secondary healthcare. Pediatr Pulmonol (2017) 52(6):729-36. doi:10.1002/ ppul.23668

32. Anderson HM, Lemanske RF, Arron JR, Holweg CTJ, Rajamanickam V, Gangnon RE, et al. Relationships among aeroallergen sensitization, peripheral blood eosinophils, and periostin in pediatric asthma development. J Allergy Clin Immunol (2017) 139(3):790-6. doi:10.1016/j.jaci.2016.05.033

33. Gabet S, Just J, Couderc R, Bousquet J, Seta N, Momas I. Early polysensitization is associated with allergic multimorbidity in PARIS birth cohort infants. Pediatr Allergy Immunol (2016) 27(8):831-7. doi:10.1111/pai.12622

34. Amin P, Levin L, Epstein T, Ryan P, LeMasters G, Khurana Hershey G, et al. Optimum predictors of childhood asthma: persistent wheeze or the asthma predictive index? JAllergy Clin Immunol Pract (2014) 2(6):709-15.e2. doi:10.1016/j.jaip.2014.08.009

35. Rø AD, Simpson MR, Storrø O, Johnsen R, Videm V, Øien T. The predictive value of allergen skin prick tests and IgE tests at pre-school age: the PACT study. Pediatr Allergy Immunol (2014) 25(7):691-8. doi:10.1111/pai.12289

36. van der Mark LB, van Wonderen KE, Mohrs J, van Aalderen WMC, ter Riet G, Bindels PJE. Predicting asthma in preschool children at high risk presenting in primary care: development of a clinical asthma prediction score. Prim Care Respir J (2014) 23(1):52-9. doi:10.4104/pcri.2014.00003

37. Stoltz DJ, Jackson DJ, Evans MD, Gangnon RE, Tisler CJ, Gern JE, et al. Specific patterns of allergic sensitization in early childhood and asthma \& rhinitis risk. Clin Exp Allergy (2013) 43(2):233-41. doi:10.1111/cea.12050

38. Llanora GV, Ming LJ, Wei LM, van Bever HPS. House dust mite sensitization in toddlers predict persistent wheeze in children between eight to fourteen years old. Asia Pac Allergy (2012) 2(3):181. doi:10.5415/apallergy. 2012.2.3.181

39. Amat F, Vial A, Pereira B, Petit I, Labbe A, Just J. Predicting the long-term course of asthma in wheezing infants is still a challenge. ISRN Allergy (2011) 2011:493624. doi:10.5402/2011/493624

40. Lodge CJ, Lowe AJ, Gurrin LC, Hill DJ, Hosking CS, Khalafzai RU, et al. House dust mite sensitization in toddlers predicts current wheeze at age 12 years. J Allergy Clin Immunol (2011) 128(4):782-8.e9. doi:10.1016/j.jaci. 2011.06.038

41. Vial Dupuy A, Amat F, Pereira B, Labbe A, Just J. A simple tool to identify infants at high risk of mild to severe childhood asthma: the persistent asthma predictive score. J Asthma (2011) 48(10):1015-21. doi:10.3109/02770903.20 11.626481

42. Caudri D, Wijga AH, Hoekstra MO, Kerkhof M, Koppelman GH, Brunekreef B, et al. Prediction of asthma in symptomatic preschool children using exhaled nitric oxide, rint and specific IgE. Thorax (2010) 65(9):801-7. doi:10.1136/ thx.2009.126912

43. Lødrup Carlsen KC, Söderström L, Mowinckel P, Håland G, Pettersen M, Munthe Kaas MC, et al. Asthma prediction in school children; the value of combined IgE-antibodies and obstructive airways disease severity score. Allergy (2010) 65(9):1134-40. doi:10.1111/j.1398-9995.2010.02344.x

44. Simpson A, Tan VY, Winn J, Svensen M, Bishop CM, Heckerman DE, et al. Beyond atopy: multiple patterns of sensitization in relation to asthma in a birth cohort study. Am J Respir Crit Care Med (2010) 181(11):1200-6. doi:10.1164/ rccm.200907-11010C

45. Marenholz I, Kerscher T, Bauerfeind A, Esparza-Gordillo J, Nickel R, Keil T, et al. An interaction between filaggrin mutations and early food sensitization improves the prediction of childhood asthma. J Allergy Clin Immunol (2009) 123(4):911-6. doi:10.1016/j.jaci.2009.01.051

46. Jackson DJ, Gangnon RE, Evans MD, Roberg KA, Anderson EL, Pappas TE, et al. Wheezing rhinovirus illnesses in early life predict asthma development in high-risk children. Am J Respir Crit Care Med (2008) 178(7):667-72. doi:10.1164/rccm.200802-309oc

47. Devulapalli CS, Carlsen KCL, Haland G, Munthe-Kaas MC, Pettersen M, Mowinckel P, et al. Severity of obstructive airways disease by age 2 years predicts asthma at 10 years of age. Thorax (2008) 63(1):8-13. doi:10.1136/ thx.2006.060616

48. Just J, Nicoloyanis N, Chauvin M, Pribil C, Grimfeld A, Duru G. Lack of eosinophilia can predict remission in wheezy infants? Clin Exp Allergy (2008) 38(5):767-73. doi:10.1111/j.1365-2222.2008.02966.x

49. Piippo-Savolainen E, Remes S, Korppi M. Does early exposure or sensitization to inhalant allergens predict asthma in wheezing infants? A 20-year follow-up. Allergy Asthma Proc (2007) 28(4):454-61. doi:10.2500/aap.2007.28.3022 
50. Eysink PE, ter Riet G, Aalberse RC, van Aalderen WM, Roos CM, van der Zee JS, et al. Accuracy of specific IgE in the prediction of asthma: development of a scoring formula for general practice. Br J Gen Pract (2005) 55(511):125-31.

51. Arshad SH, Bateman B, Matthews SM. Primary prevention of asthma and atopy during childhood by allergen avoidance in infancy: a randomised controlled study. Thorax (2003) 58(6):489-93. doi:10.1136/thorax.58.6.489

52. Kotaniemi-Syrjanen A, Reijonen TM, Romppanen J, Korhonen K, Savolainen K, Korppi M. Allergen-specific immunoglobulin E antibodies in wheezing infants: the risk for asthma in later childhood. Pediatrics (2003) 111(3): e255-61. doi:10.1542/peds.111.3.e255

53. Illi S, von Mutius E, Lau S, Nickel R, Niggemann B, Sommerfeld C, et al. The pattern of atopic sensitization is associated with the development of asthma in childhood. J Allergy Clin Immunol (2001) 108(5):709-14. doi:10.1067/ mai.2001.118786

54. Kurukulaaratchy RJ, Matthews S, Holgate ST, Arshad SH. Predicting persistent disease among children who wheeze during early life. Eur Respir J (2003) 22(5):767-71. doi:10.1183/09031936.03.00005903

55. Guilbert TW, Morgan WJ, Krawiec M, Lemanske RF, Sorkness C, Szefler SJ, et al. The prevention of early asthma in kids study: design, rationale and methods for the childhood asthma research and education network. Control Clin Trials (2004) 25(3):286-310. doi:10.1016/j.cct.2004.03.002

56. Castro-RodríGuez JA, Holberg CJ, Wright AL, Martinez FD. A clinical index to define risk of asthma in young children with recurrent wheezing. Am J Respir Crit Care Med (2000) 162(4):1403-6. doi:10.1164/ajrccm.162.4.9912111

57. Simpson A, Tan VYF, Winn J, Svensén M, Bishop CM, Heckerman DE, et al. Beyond atopy. Am J Respir Crit Care Med (2010) 181(11):1200-6. doi:10.1164/ rccm.200907-11010c

58. Johansson SGO, Hourihane JOB, Bousquet J, Bruijnzeel-Koomen C, Dreborg S, Haahtela T, et al. A revised nomenclature for allergy: an EAACI position statement from the EAACI nomenclature task force. Allergy (2008) 56(9):813-24. doi:10.1111/j.1398-9995.2001.00002.x-i1

59. Rodriguez-Martinez CE, Sossa-Briceno MP, Castro-Rodriguez JA. Factors predicting persistence of early wheezing through childhood and adolescence: a systematic review of the literature. J Asthma Allergy (2017) 10:83-98. doi:10.2147/jaa.s128319

60. Maas T, Kaper J, Sheikh A, Knottnerus JA, Wesseling G, Dompeling E, et al. Mono and multifaceted inhalant and/or food allergen reduction interventions for preventing asthma in children at high risk of developing asthma. Cochrane Database Syst Rev (2009) 3:CD006480. doi:10.1002/14651858.CD006480.pub2
61. Chan-Yeung M, Ferguson A, Watson W, Dimich-Ward H, Rousseau R, Lilley M, et al. The Canadian childhood asthma primary prevention study: outcomes at 7 years of age. J Allergy Clin Immunol (2005) 116(1):49-55. doi:10.1016/j. jaci.2005.03.029

62. Platts-Mills T, Vaughan J, Squillace S, Woodfolk J, Sporik R. Sensitisation, asthma, and a modified Th2 response in children exposed to cat allergen: a population-based cross-sectional study. Lancet (2001) 357(9258):752-6. doi:10.1016/s0140-6736(00)04168-4

63. Young MC. Taking the leap earlier. Curr Opin Pediatr (2015) 27(6):736-40. doi:10.1097/mop.0000000000000291

64. Kramer MS, Kakuma R. Maternal dietary antigen avoidance during pregnancy or lactation, or both, for preventing or treating atopic disease in the child. Evid Based Child Health (2014) 9(2):447-83. doi:10.1002/ebch.1972

65. Alvisi P, Brusa S, Alboresi S, Amarri S, Bottau P, Cavagni G, et al. Recommendations on complementary feeding for healthy, full-term infants. Ital J Pediatr (2015) 41:36. doi:10.1186/s13052-015-0143-5

66. Schäfer T, Bauer C-P, Beyer K, Bufe A, Friedrichs F, Gieler U, et al. S3-guideline on allergy prevention: 2014 update. Allergo J Int (2014) 23(6):186-99. doi:10.1007/s40629-014-0022-4

67. Gold DR, Adamkiewicz G, Arshad SH, Celedon JC, Chapman MD, Chew GL, et al. NIAID, NIEHS, NHLBI, MCAN workshop report: the indoor environment and childhood asthma: implications for home environmental intervention in asthma prevention and management. J Allergy Clin Immunol (2017). doi:10.1016/j.jaci.2017.04.024

68. Wright A. The epidemiology of the atopic child: who is at risk for what? J Allergy Clin Immunol (2004) 113(1):S2-7. doi:10.1016/j.jaci.2003.09.050

Conflict of Interest Statement: The authors declare that the research was conducted in the absence of any commercial or financial relationships that could be construed as a potential conflict of interest.

Copyright (c) 2017 Moustaki, Loukou, Tsabouri and Douros. This is an open-access article distributed under the terms of the Creative Commons Attribution License (CC BY). The use, distribution or reproduction in other forums is permitted, provided the original author(s) or licensor are credited and that the original publication in this journal is cited, in accordance with accepted academic practice. No use, distribution or reproduction is permitted which does not comply with these terms. 